\title{
Biurowość w czasach pandemii. System EZD podczas epidemii COVID-19 w jednostkach administracji samorządowej i rządowej w terenie ${ }^{1}$
}

\author{
Marcin Smoczyński
}

Uniwersytet Mikołaja Kopernika w Toruniu / Nicolaus Copernicus University in Toruń (Poland) marsmo@umk.pl, ORCID 0000-0002-4111-0201

\section{STRESZCZENIE}

Artykuł powstał w oparciu o badania przeprowadzone $\mathrm{w}$ ramach realizacji projektu „Biurowość w czasach pandemii. Wpływ epidemii COVID-19 na informatyzację biurowości w administracji publicznej", a jego głównym celem było określenie roli i znaczenia wykorzystania systemu EZD w okresie epidemii COVID-19 w jednostkach administracji samorządowej i rządowej w terenie. Na artykuł złożyły się - oprócz wprowadzenia i podsumowania - następujące części: System elektronicznego zarządzania dokumentacją (gdzie nakreślono w zarysie historię i prawne ramy wykorzystania systemów EZD w polskiej administracji), O badaniu (zawierającej opis poszczególnych etapów realizacji wspomnianego powyżej projektu badawczego i zgromadzonych danych), System EZD w badanych jednostkach - uwagi ogólne (w tej części omówiono proces wdrażania i wybrane aspekty użytkowania systemu EZD w jednostkach objętych badaniem), Organizacja pracy w czasie pandemii COVID-19 (przedstawienie praktycznych aspektów funkcjonowania urzędów w nowej, zmienionej pandemicznymi obostrzeniami rzeczywistości), System EZD w czasie pandemii (określenie roli systemu EZD w czasie epidemii koronawirusa SARS-CoV-2), Przygotowanie techniczne (ocena przygotowania technicznego oraz przybliżenie poczynionych inwestycji w sprzęt informatyczny niezbędny do pracy biurowej) oraz Przygotowanie merytoryczne (w tej części przedstawiono zapotrzebowanie urzędników na formy doszkalające).
SŁOWA KLUCZOWE pandemia, COVID-19, informatyzacja biurowości, e-usługi, administracja samorządowa, informatyzacja, biurowość, system EZD, SARS-CoV-2

1 Artykuł zawiera wyniki badań przeprowadzonych jako część realizacji grantu „Biurowość w czasach pandemii. Wpływ epidemii COVID-19 na informatyzację biurowości w administracji publicznej”. Grant uzyskany w ramach konkursu „CRUSH - badania nad pandemią COVID-19 realizowane na UMK przez przedstawicieli Nauk Społecznych i Humanistycznych” został sfinansowany w ramach programu Inicjatywa Doskonałości - Uczelnia Badawcza. Projekt realizowany w latach 2020-2021 przez badaczy z Uniwersytetu Mikołaja Kopernika w Toruniu (dalej: UMK): Katarzynę Pepłowską i Marcina Smoczyńskiego. Wszystkie kwestionariusze przygotowane w związku z badaniem oraz odpowiedzi przesłane przez respondentów udostępniono jako raw data na stronie internetowej projektu: https://dobrepraktyki.umk.pl/. Pozostałe dane badawcze zgromadzone w toku realizacji projektu przechowywane są w siedzibie Wydziału Nauk Historycznych UMK, ul. Wł. Bojarskiego 1, 87-100 Toruń. 


\section{Office practices in times of pandemic. EDM system during COVID-19 outbreak in local and central government units in the field}

\begin{abstract}
The article is based on research conducted under the project "Office practices in times of pandemic. The impact of the COVID-19 epidemic on digitization of office work in public administration", and its main objective was to determine the role and importance of the use of EDM system during the COVID-19 outbreak in local and central government administration units in the field. The article comprises - besides the introduction and summary - the following parts: Electronic Document Management System (where the history and legal framework of the use of EDM systems in Polish administration is outlined), About the study (describing the different stages of the above mentioned research project implementation and the collected data), EDM system in the surveyed units - general observations (this part discusses the implementation process and selected aspects of the use of the EDM system in the surveyed units), Organization of work during the COVID-19 pandemic (presentation of practical aspects of operation of the units in the new reality, changed by the pandemic strictures), EDM system during the pandemic (definition of the role of the EDM system during the SARS-CoV-2 coronavirus epidemic), Technical preparation (assessment of technical preparation and approximation of the investments made in IT equipment necessary for office work), and Substantive preparation (this section presents the needs of officials for additional training).
\end{abstract}

KEYWORDS

pandemic, COVID-19, office digitization, e-services, local government, computerization, office, EDM system, SARS-CoV-2

\section{Słowo wstępne}

Administracja nie jest organizmem niezmiennym ani niepodlegającym przeobrażeniom, jest to raczej aparat ulegający ciągłym zmianom i reagujący na przemiany zachodzące w społeczeństwach. Ewoluuje w odpowiedzi na istotne wydarzenia. Należą do nich z pewnością wielkie konflikty zbrojne². Niewątpliwy

2 Np. amerykański aparat administracyjny rozrastał się w trakcie trwania większości z wojen, w które zaangażowały się Stany Zjednoczone. Wojna amerykańsko-hiszpańska doprowadziła do rozrostu administracji rządowej, spowodowała konieczność zwiększenia jej budżetu oraz podwyższyła deficyt w finansach publicznych, zob: O. Kraines, The President versus Congress: The Keep Commission, 1905-1909: First Comprehensive Presidential Inquiry into Administration, „The Western Political Quarterly" 1970, t. 23, nr 1, s. 5; R.C. Moe, Reorganizing the Executive Branch in the 20th Century: Landmark Commissions, Waszyngton, D.C. 2002, s. 20, https://digital.library.unt.edu/ark:/67531/metadc813148/ [dostęp: 13.05.2021]. Podobnie było po I wojnie światowej, która spowodowała w aparacie administracyjnym Stanów Zjednoczonych - tak jak i wielu innych państw, które uczestniczyły w tym konflikcie - rozrost struktur, zwiększenie liczby pracowników potrzebnych do obsługi biurowej oraz podniesienie kosztów, zob.: R.C. Moe, op.cit., s. 29-30. II wojna światowa również wywarła istotny wpływ na kształt amerykańskiej administracji, co w efekcie doprowadziło do powołania I i II Komisji Hoovera. Efekty ich prac stały się natomiast katalizatorem dla zarządzania dokumentacją, zob.: W.E. Pemberton, Struggle for the New Deal: Truman and the Hoover Commission, „Presidential Studies Quarterly” 1986, t. $16, \mathrm{nr}$ 3, s. 512-515. 
wpływ na aparaty administracyjne państw miały także sytuacje polityczne ${ }^{3}$ i ekonomiczne $e^{4}$ oraz rozwój nauki ${ }^{5} \mathrm{i}$ technologii ${ }^{6}$.

W tak zarysowanym kontekście rzadko zwraca się uwagę na czynniki chorobowe. Te jednak również można zaliczyć do faktorów wpływających na kształt administracji. Warto wspomnieć choćby jedną z największych epidemii w najnowszej historii świata - pandemię grypy hiszpanki, której największe nasilenie przypadło na okres 12 miesięcy w latach 1918-1919, a jej trzy fale zaatakowały Europę, Azję, Afrykę oraz Amerykę Północną. Wyjątkowo groźna odmiana podtypu H1N1 wirusa A grypy w samej tylko Europie spowodowała ok. 2,6 mln. zgonów 7 . Grypa hiszpanka uderzyła także w klasę urzędniczą, która - ze względu na społeczny charakter pracy - była mocno narażona na ekspozycję na wirusa. Nowojorski departament zdrowia informował, że urzędnicy stanowili grupę zawodową z drugą najwyższą umieralnością. Łącznie w tej profesji odnotowano zgony 439 mężczyzn i 289 kobiet oraz oszacowano, że w szczytowym okresie epidemii codziennie umierało około 10 pracowników biurowych ${ }^{8}$. Pandemia z pierwszej

3 Przykładem może być okres zaborów i ponad stuletnia przerwa w ciągłości państwowości, która spowodowała, że polska administracja publiczna rozwijała się w sposób odmienny na tle większości państw europejskich. Zahamowano rozkwit kultury oraz tradycji administracyjnej, a powstanie w XIX w. wykwalifikowanej i ugruntowanej społecznie, w pełni polskiej klasy urzędniczej w dużej mierze uniemożliwiono.

4 Większości działań polskich komisji dla usprawnienia administracji powołanych w okresie międzywojennym przyświecał cel ekonomizacji funkcjonowania administracji, zob.: M. Smoczyński, Racjonalizacja biurowości w działaniach komisji dla usprawnienia administracji publicznej w II Rzeczypospolitej, [w:] Dzieje biurokracji, t. 10, red. A. Górak, J. Kukarina, D. Magier, Lublin 2019, s. 143-158.

5 Nie można nie doceniać wydajnego komponentu, który do administracji wprowadziły nauki o ekonomii i zarządzaniu, szczególnie w zakresie zwiększania efektywności pracy urzędników; zob.: M. Smoczyński, Amerykańskie i polskie początki zarzq̨dzania dokumentacją, [w:] Pogranicza Archiwistyki, Toruńskie Konfrontacje Archiwalne, t. 6, red. W. Chorążyczewski, A. Rosa, Toruń 2019, s. 146-148.

6 Wdrażanie do biurowości nowych technologii ma od końca XVIII w. tryb ciągły. Wynalazczość z zakresu mechanizacji pracy biurowej postępowała również w Polsce, gdzie jednak jeszcze w 1955 r. poziom umaszynowienia administracji oceniano jako niedostateczny, zob.: Komunikat Centralnej Komisji Usprawnienia Administracji Publicznej przy Prezesie Rady Ministrów, nr 3, Zagadnienie mechanizacji pracy biurowej, oprac. W. Jarzębowski, W. Jaroszewska, Warszawa 1955, s. 12.

7 A. Erkoreka, The Spanish influenza pandemic in occidental Europe (1918-1920) and victim age, „Influenza Other Respir Viruses” 2010, nr 4 (2), s. 86.

8 E.T. Ewing, J.S. Reznick, Clerks wearing masks. Building Historical Empathy while Teaching the 1918 Influenza Epidemic, https://www.historians.org/publications-and-directories/perspectives-on-history/december-2020/clerks-wearing-masks-building-historical-empathy-while-teaching-the-1918-influenza-epidemic [dostęp: 5.05.2021]. 
poł. XX w. zebrała krwawe żniwo i spowodowała wiele zgonów, implikując tym samym konieczność uzupełniania kadr zatrudnianych w urzędach administracji publicznej. Skutki epidemii hiszpanki, w tym w sektorze administracji, były odczuwalne co najmniej do połowy okresu międzywojennego ${ }^{9}$.

Równo 100 lat później, w 2019 r., ludzkość po raz kolejny musiała zmierzyć się z zagrożeniami, które przyniosła ze sobą epidemia. Pod koniec tego roku rozpoczęła się światowa pandemia koronawirusa SARS-CoV-2 i wywołanej nim choroby układu oddechowego COVID-19. Ogólnoświatowy kryzys spowodował daleko idące zmiany, które objęły gospodarkę, ekonomię, życie społeczne, kulturalne, a także funkcjonowanie administracji publicznej. Restrykcyjne obostrzenia ograniczające wiele aspektów ludzkiej aktywności (w tym szczególnie życie zawodowe) spowodowały konieczność przeniesienia działalności administracji do świata cyfrowego. Wydaje się więc, że część z polskich urzędów mogła być do sytuacji kryzysowej przygotowana lepiej od pozostałych. Mowa o jednostkach, w których w pełni wdrożono elektroniczną kancelarię opartą o system elektronicznego zarządzania dokumentacją (dalej: EZD). Niniejszy artykuł - jako pokłosie realizacji projektu badawczego pt. „Biurowość w czasach pandemii. Wpływ epidemii COVID-19 na informatyzację biurowości w administracji publicznej” - za główny cel stawia sobie określenie roli i znaczenia wykorzystania systemu EZD dla realizacji działań w warunkach pracy zdalnej w jednostkach administracji samorządowej i rządowej w terenie podczas epidemii COVID-19.

\section{O badaniu}

Badanie biurowości w okresie pandemii zostało zrealizowane w dwóch oddzielnych częściach. Pierwsza z nich dotyczyła diagnozy funkcjonowania jednostek, które działały w oparciu o rozwiązania tradycyjne ${ }^{10}$. Druga cześć stanowiła analizę działalności urzędów, w których wdrożono system EZD.

9 O świadomości zagrożenia i podjętych przeciwdziałaniach świadczy choćby wykonana 28 października 1918 r. fotografia amerykańskich urzędniczek pracujących w maseczkach ochronnych, zob.: National Archives, Record Group 165, Records of the War Department General and Specific Staffs, 1860-1952, Medical Department - Influenza Epidemic 1918 - Masks for protection against influenza. Girl clerks in New York at work with masks carefully tied about their faces, sygn. 165-WW-269B24.

10 Zob. niniejszy tom: K. Pepłowska, Biurowość w czasach pandemii. Wpływ epidemii COVID-19 na informatyzację biurowości w jednostkach administracji samorzq̨owej. 
Pierwszym z etapów badania było wytypowanie jednostek. Intencją było zlokalizowanie instytucji, w których przeprowadzono pełne wdrożenie systemu EZD przed wybuchem epidemii koronawirusa SARS-CoV-2 oraz takich, w których decyzję tę podjęto $w$ trakcie trwania pandemii. W tym zakresie obrano dwojaki kierunek działań - dane uzyskiwano drogą dostępu do informacji publicznej (po przesłaniu zapytań do urzędów) oraz na podstawie komunikatów umieszczonych na stronie internetowej EZD PUW ${ }^{11}$. Dzięki podjętym krokom udało się wytypować do badania 29 jednostek organizacyjnych, w których wdrożenie EZD nastąpiło przed wybuchem epidemii COVID-19. Na tę grupę złożyły się: 3 urzędy gminy, 5 urzędów miejskich, 4 starostwa powiatowe, 4 urzędy marszałkowskie oraz 13 urzędów wojewódzkich. Dodatkowo skontaktowano się z grupą 23 instytucji (11 urzędów gminy, 2 urzędy miejskie, 10 starostw powiatowych), w których decyzja o zmianie systemu wykonywania czynności kancelaryjnych na elektroniczny nastąpiła po 1 marca 2020 r., choć jednostki te nie były objęte pełnym badaniem. Skierowano do nich wniosek o udostępnienie informacji publicznej w zakresie powodów podjęcia decyzji o przejściu na system EZD i ew. wpływu na nią sytuacji epidemicznej.

Kolejny etap badania stanowiła ankietyzacja. Za pośrednictwem platformy ePUAP przesłano do 29 jednostek ankietę wygenerowaną przy wykorzystaniu narzędzia System Badań Ankietowych Uniwersytetu Mikołaja Kopernika w Toru$n^{1} u^{12}$. Oparto je na wolnym oprogramowaniu LimeSurvey, które umożliwiło przygotowanie i przesłanie kwestionariusza, a później gromadzenie i analizowanie odpowiedzi udzielonych przez respondentów ${ }^{13}$. Ankieta składała się z 20 pytań otwartych i zamkniętych oraz typu mieszanego (obok odpowiedzi sugerowanych umożliwiono dodanie autorskiego komentarza). Zapytania dotyczyły m.in. oceny wykorzystywanego systemu EZD, jego awaryjności i przydatności w okresie pandemii, kwestii szkoleń, wydajności pracy, osobistych odczuć w związku ze zmianą trybu pracy oraz dobrych praktyk wdrożonych w obliczu sytuacji kryzysowej. Ankieta była aktywna w okresie od 19 stycznia do 1 marca $2021 \mathrm{r}^{14}$

11 Zestawienie instytucji wdrażających system EZD PUW na podstawie porozumienia z wojewodą podlaskim, https://ezd.gov.pl/www/ezd/partnerzy [dostęp: 6.05.2021].

12 System Badań Ankietowych, https://www.uci.umk.pl/index.php/System_Badań_Ankietowych [dostęp: 6.05.2021].

13 Szczegółowe informacje dotyczące wykorzystanego w badaniu narzędzia dostępne są na stronie internetowej: LimeSurvey, https://www.limesurvey.org [dostęp: 6.05.2021].

14 Łącznie uzyskano 802 odpowiedzi. 
Przedmiotem badań były więc zarówno urzędy, ustalenie stanu faktycznego na podstawie danych pochodzących bezpośrednio od jednostek organizacyjnych drogą oficjalną, jak i urzędnicy - ich opinie, doświadczenia oraz subiektywne odczucia.

Oddzielny zasób materiałów o charakterze źródłowym uzyskano drogą dostępu do informacji publicznej. Do każdej z jednostek objętych badaniem przesłano wniosek zawierający zapytania m.in. o: liczbę pism wpływających do podmiotu drogą elektroniczną w 2019 r. i w 2020 r. (w ujęciu miesięcznym), harmonogram i proces wdrażania systemu EZD w podmiocie, inwestycje poczynione w okresie pandemii oraz awaryjność systemu ${ }^{15}$.

Dzięki zastosowanej metodologii badań otrzymano szeroki wachlarz 1192 odpowiedzi uzyskanych drogą ankietyzacji oraz dostępu do informacji publicznej. Intencją koordynatorów badania była pełna anonimowość jego wszystkich uczestników. Nie zdecydowano się więc na prezentację wyników w ujęciu indywidualnym, lecz uśrednionym, wobec czego powoływano się na całość zgromadzonego materiału.

\section{System EZD w badanych jednostkach - uwagi ogólne}

Jednostki objęte badaniem wdrażały system EZD na przestrzeni lat 20112020, co należy przełożyć na zróżnicowane doświadczenia i praktyki badanych instytucji. Największy odsetek urzędów wdrożył system w okresie od 2011 do 2014 r. (wykres 1). Liczba ta malała z każdym rokiem, a materiał źródłowy zebrany drogą dostępu informacji publicznej potwierdził dane uzyskane poprzez ankietyzację.

Pełne przejście na kancelarię elektroniczną stanowi niewątpliwie duże przedsięwzięcie organizacyjne, nie tylko pod względem technicznym, ale - przede wszystkim - merytorycznym. Musi być to więc proces rozłożony w długiej perspektywie czasowej. Dla zdecydowanej większości badanych jednostek okres od podjęcia decyzji o odejściu od trybu tradycyjnego do wdrożenia systemu EZD trwał od 12 do 24 miesięcy $^{16}$.

15 Łącznie uzyskano 390 odpowiedzi.

16 Na podstawie dokumentacji zebranej w toku projektu. 
Wykres 1. Wdrożenia systemu EZD w badanych jednostkach

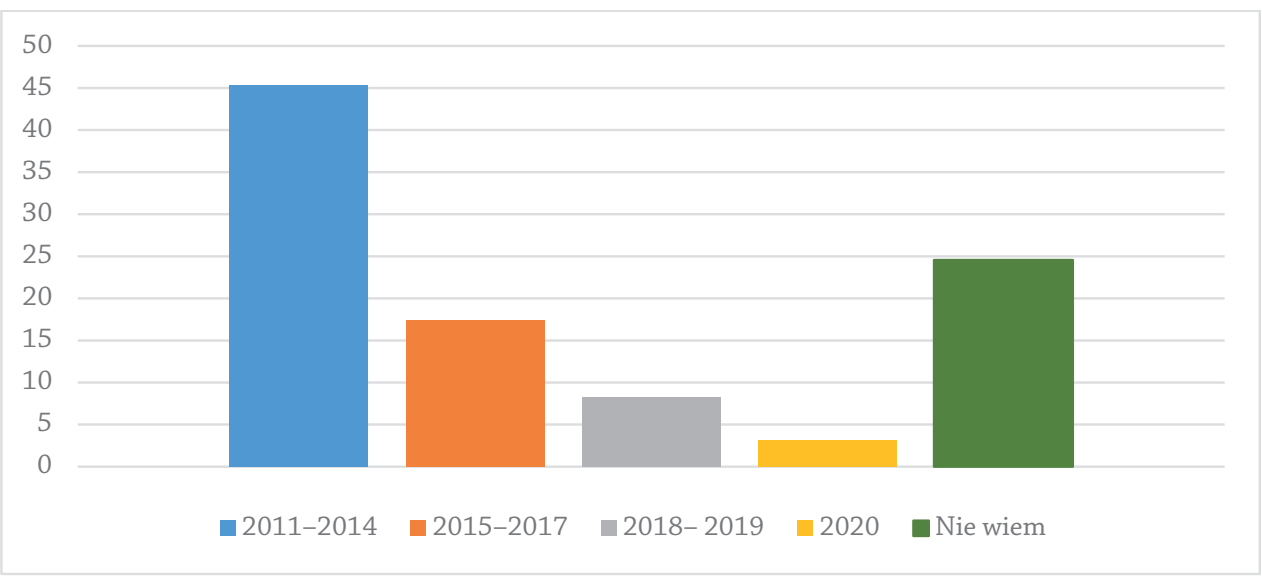

Opracowanie własne na podstawie dokumentacji zebranej w toku projektu.

Ponad 80\% jednostek nie uwzględniło procesu wdrożenia systemu EZD w swojej strategii działalności. Planowanie w tym zakresie deklarowało 20\%, a w tym jedynie 5\% na podstawie zapisów zawartych w dokumentach o znaczeniu strategicznym. Niektóre z urzędów opracowały raport wyjściowy, mocą wewnętrznych normatywów omawiający stan rzeczywisty oraz określający oczekiwania i rekomendacje, choć niejednokrotne były przypadki ujmowania tych informacji wyłącznie w rocznych planach działań. Odnotowano także przykłady wdrożenia systemu EZD jako pokłosia szerszych działań informatyzacji samorządu terytorialnego. Jako jednostkowe należy uznać zjawisko ujmowania procesu przejścia na elektroniczną kancelarię w długoterminowej strategii rozwoju jednostki ${ }^{17}$.

Wdrożenie w pełni elektronicznej kancelarii nie zawsze następowało jako realizacja postulatu wprowadzenia wydajniejszej i korzystniejszej pod względem ekonomicznym formy pracy. Należy odnotować, że dla niektórych jednostek wdrożenie systemu EZD było konsekwencją zapisów ustawy o informatyzacji ${ }^{18}$ i rozporządzenia Prezesa Rady Ministrów z 2011 r. oraz ustaleń organów administracji rządowej, a dla niektórych jedynie poleceniem organów nadrzędnych ${ }^{19}$.

Wdrożenie systemu EZD niewątpliwie wymaga przemyślanego planu działań. Wśród czynności koniecznych powinno być m.in. przeprowadzenie studiów wstępnych, analizy normatywów kancelaryjnych oraz wykorzystywanych dotych-

17 Ibidem.

18 Ustawa z dnia 17 lutego 2005 r. o informatyzacji działalności podmiotów realizujących zadania publiczne (Dz. U. 2021, r. poz. 670).

19 Na podstawie dokumentacji zebranej w toku projektu. 
czas narzędzi informatycznych. Na podstawie zebranego materiału badawczego można stwierdzić, że wiele jednostek zrezygnowało z przeprowadzenia czynności początkowych, nie określiło swoich oczekiwań, nie ustaliło gotowości urzędu do wdrożenia systemu, nie przeprowadziło także analizy skali wykorzystywanych dotychczas rozwiązań - i to pomimo podkreślania wagi początkowego etapu prac już w 2014 r. ${ }^{20}$

Nieco korzystniej zarysował się proces wdrożenia EZD w zgodzie z przyjętym wcześniej harmonogramem. Ogółem nie mniej niż 48\% urzędów system EZD wprowadziło według określonego uprzednio planu działań, jednak większość z nich (aż 52 \%) wdrożyła go bez harmonogramu. Niektóre jednostki schemat uruchomienia systemu ustalały na bieżąco $z$ organem nadrzędnym i w odpowiedzi na napotykane trudności. Działania czynione bez opracowanego wcześniej harmonogramu należy ocenić negatywnie - spontaniczność w tym zakresie jest reakcją na bieżące sytuacje i problemy, a zarządzanie narastającą dokumentacją powinno być procesem przemyślanym w długiej perspektywie czasowej.

Doświadczenia i przyjęte rozwiązania w zakresie wdrażania EZD cechowały się dużą różnorodnością. W zdecydowanej większości harmonogram wprowadzania nowych rozwiązań był rozpisany średnio na 2 lata, niektóre podmioty określały jedynie etapy, a wśród nich: I. implementacja wersji testowej i szkolenia, II. uruchomienie wersji produkcyjnej systemu EZD jako wspomagającego czynności kancelaryjne oraz III. pełne wdrożenie wersji produkcyjnej systemu jako podstawowego sposobu dokumentowania przebiegu załatwienia spraw. Nie można jednak zbudować jednolitego obrazu stosowanych działań praktycznych. Odnotowano bowiem liczne przykłady podziału harmonogramu wg czynności kancelaryjnych. Podmioty, które nie opracowały programu wdrożenia, zmuszone były kierować się końcowym terminem uruchomienia systemu, niekiedy przygotowując dokumenty robocze porządkujące własne działania wewnętrzne w aspekcie przygotowania technicznego, rozwiązań organizacyjnych, pozyskania kompleksowej wiedzy o rodzajach dokumentacji, umiejętności cyfrowych pracowników, itd. Na szczególne podkreślenie zasługują praktyki wskazywania osób

20 W 2014 r. tylko co jedenasty urząd posiadał dokument strategiczny w zakresie rozwoju teleinformatycznego. W sektorze administracji samorządowej taki dokument posiadało jedynie 8\% urzędów. Urzędy administracji państwowej taki dokument posiadły 4 razy częściej (32\%). Jednocześnie zaobserwowano spadek tego odsetka wśród urzędów administracji państwowej; zob.: Wpływ cyfryzacji na działanie urzędów administracji publicznej w Polsce w 2014 r. Raport Ministerstwa Administracji i Cyfryzacji, s. 10, https://dane.gov.pl/media/resources/20150227/ PBSMACCyfryzacjaFIN2014.pdf [dostęp: 30.05.2021]. 
odpowiedzialnych za realizację poszczególnych etapów oraz opisywania procedur postępowania $\mathrm{z}$ dokumentacją podczas wdrażania poszczególnych funkcjonalności systemu ${ }^{21}$.

Zdecydowana większość, bo aż 76\% badanych jednostek, nie dokonała zmian w strukturze organizacyjnej w związku z wdrożeniem systemu EZD. Wśród tej grupy częstą praktyką było powoływanie zespołu ds. wdrożenia systemu EZD złożonego z pracowników różnych komórek. W pozostałych jednostkach (24\%) powoływano nowe komórki organizacyjne. Często powoływano także koordynatora ds. wdrożenia systemu w każdej z komórek ${ }^{22}$. W niektórych urzędach uruchomienie systemu powierzano wyłącznie informatykom, co należy odebrać zdecydowanie negatywnie - system obsługujący biurowość musi być nie tylko projektowany, ale także wdrażany w porozumieniu i przy udziale doświadczonych specjalistów z zakresu zarządzania dokumentacją.

Ankietowani urzędnicy w zdecydowanej większości pozytywnie ocenili działanie systemu EZD w swojej pracy. Ponad 88\% wskazało, że system EZD jest narzędziem usprawniającym funkcjonowanie jednostki ${ }^{23}$. Ponadto dla przeważającej liczby respondentów system to oprogramowanie pomocne i funkcjonalne (wykres 2). Trzeba jednak mieć na uwadze także grupę 39\% ankietowanych, dla której EZD wymaga usprawnienia oraz 13,5\%, która określiła system jako mało elastyczny.

System EZD ma zatem szerokie grono zwolenników, choć należy mieć także na uwadze grupę sceptyków, a nawet zdecydowanych przeciwników. Trzeba jednak podkreślić, że większość ankietowanych doceniła jego walory, w tym szczególnie jako komponent pracy administracji zwiększający jej wydajność oraz narzędzie funkcjonalne i pomocne.

\section{Organizacja pracy w czasie pandemii COVID-19}

Organizacja pracy urzędów, w tym ograniczenia w ich funkcjonowaniu, w zdecydowanej większości badanych jednostek były efektem przepisów wewnętrznych wydanych przez kierowników na podstawie wytycznych organów wyższego stopnia. Praktyka ta była powszechna, wynikała bowiem z przepisów prawa -

21 Na podstawie dokumentacji zebranej w toku projektu.

22 Ibidem.

23 Ibidem. 
Wykres 2. Ocena systemu EZD

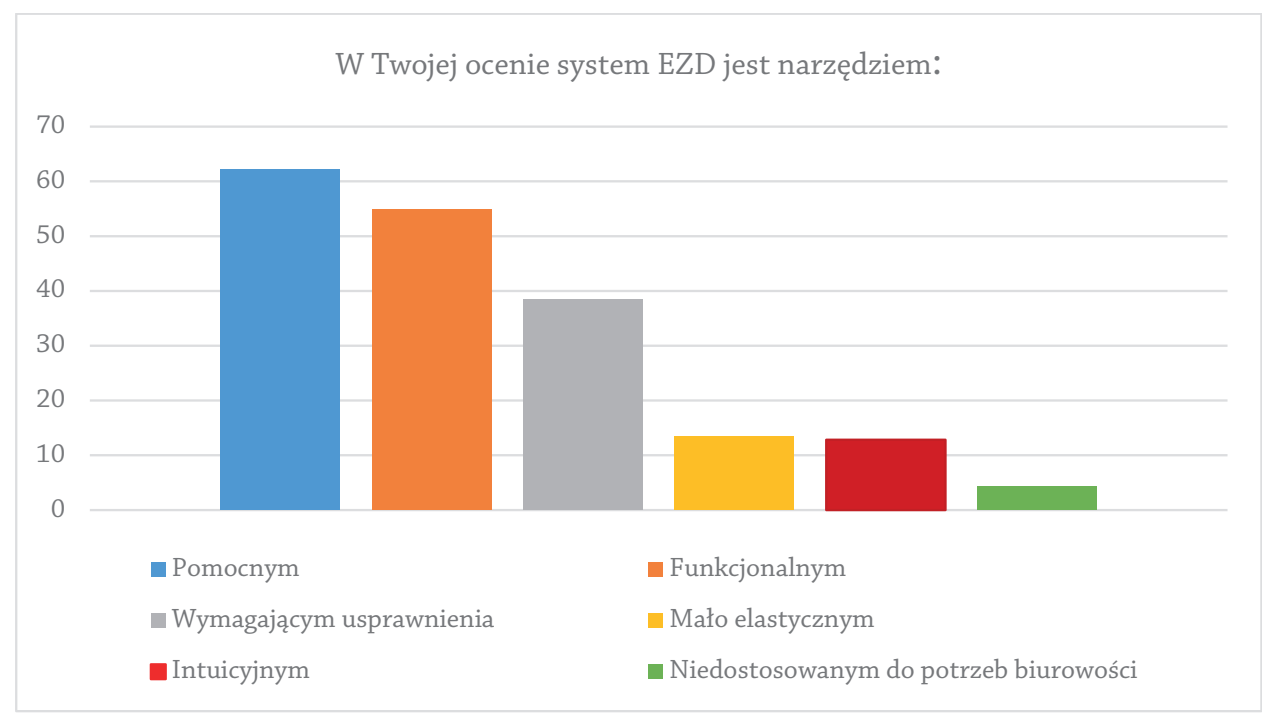

Opracowanie własne na podstawie dokumentacji zebranej w toku projektu.

Rozporządzenia Ministra Zdrowia z dnia 13 marca 2020 r. w sprawie ogłoszenia na obszarze Rzeczypospolitej Polskiej stanu zagrożenia epidemicznego. Na podstawie $\S 8$ poruczono kierownikom jednostek organizacyjnych zadanie podjęcia decyzji o rodzaju i formie wprowadzonych ograniczeń ${ }^{24}$. Zobowiązano tym samym szczebel kierowniczy do podjęcia decyzji o rodzaju i formie wprowadzonych obostrzeń oraz upublicznienia informacji o nich na stronie internetowej i w sie-

24 Rozporządzenie Ministra Zdrowia z dnia 13 marca 2020 r. w sprawie ogłoszenia na obszarze Rzeczypospolitej Polskiej stanu zagrożenia epidemicznego (Dz. U. 2020, poz. 433). Później wydawano rozporządzenia Rady Ministrów w sprawie ustanowienia określonych ograniczeń, nakazów i zakazów w związku z wystąpieniem stanu epidemii, gdzie regulowano ograniczenia dotyczące m.in. działalności urzędów. Aktualne na dany czas obostrzenia w funkcjonowaniu urzędów administracji publicznej, zob.: $\$ 13$ rozporządzenia z 10 kwietnia 2020 r. (Dz. U. 2020, poz. 658, § 13), §13 rozporządzenia z 19 kwietnia 2020 r. (Dz. U. 2020, poz. 697), § 13 rozporządzenia z 2 maja 2020 r. (Dz. U. 2020, poz. 792), § 13 rozporządzenia z 16 maja 2020 r. (Dz. U. 2020, poz. 878), § 14 rozporządzenia z 30 maja 2020 r. (Dz. U. 2020, poz. 964), § 15 rozporządzenia z 20 czerwca 2020 r. (Dz. U. 2020, poz. 1066), § 21 rozporządzenia z 8 sierpnia 2020 r., (Dz. U. 2020, poz. 1356), § 24 rozporządzenia z 10 października 2020 r. (Dz. U. 2020, poz. 1758), § 21 rozporządzenia z 26 listopada 2020 r. (Dz. U. 2020, poz. 2091), § 21 rozporządzenia z 1 grudnia 2020 r. (Dz. U. 2020, poz. 2132), § 22 rozporządzenia z 21 grudnia 2020 r. (Dz. U. 2020, poz. 2316), § 22 rozporządzenia z dnia 26 lutego 2021 r. (Dz. U. 2021, poz. 447) oraz § 21 rozporządzenia z 21 marca 2021 r. obowiązującego do 9 kwietnia 2021 r. (Dz. U. 2021, poz. 512). 
dzibie urzędu ${ }^{25}$. Powszechną praktyką było wprowadzanie szczegółowych ograniczeń w oparciu o rekomendacje centralnych organów administracji rządowej oraz zaleceń Głównego Inspektoratu Sanitarnego (w zależności od stanu zagrożenia epidemicznego).

Urzędy pracowały w trybie hybrydowym i rotacyjnym. W większości instytucji wydano polecenie pracy zdalnej i unormowano ją regulacją wewnętrzną (wykres 3). Można również zaobserwować, że regulaminy pracy świadczonej poza stacjonarną siedzibą obowiązały w większych jednostkach organizacyjnych, w mniejszych pracy zdanej oddzielnie nie normowano. Organizacja dokonywała się w nich zgodnie z przepisami prawa powszechnie obowiązującego ${ }^{26}$.

Wykres 3. Organizacja pracy zdalnej w okresie epidemii koronawirusa SARS-CoV-2

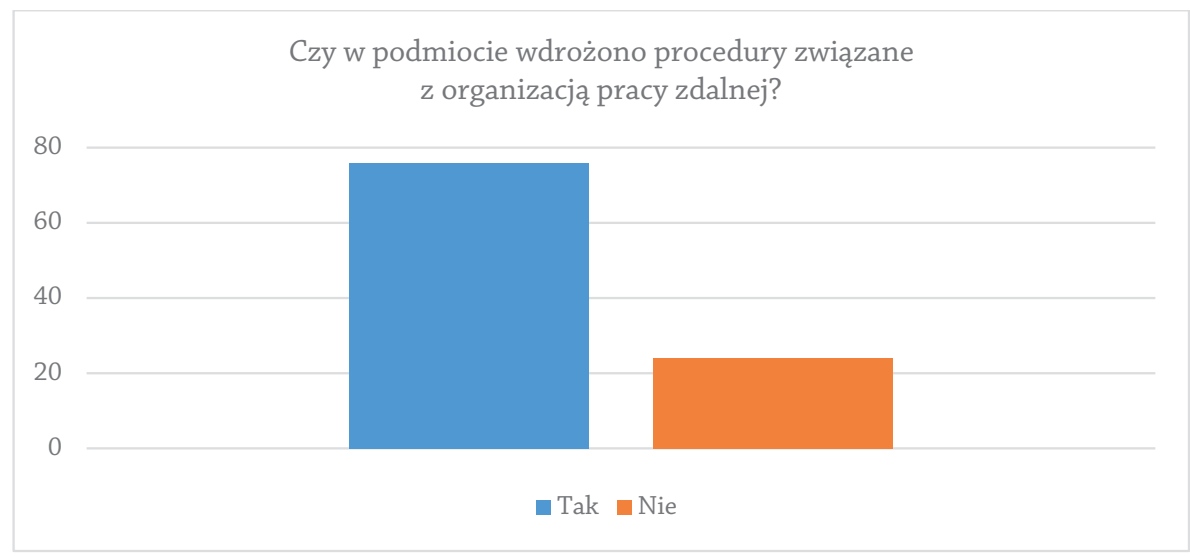

Opracowanie własne na podstawie dokumentacji zebranej w toku projektu.

Wprowadzane regulaminy pracy zdalnej cechowały się różnorodną głębią informacyjną. W większości badanych przypadków nakazano pracownikom korzystanie wyłącznie z połączenia VPN, ewentualnie z sieci prywatnej, zakazując łączeń z publicznych i otwartych sieci. Odwoływano się do polityki bezpieczeństwa informacji, instrukcji zarządzania systemami informatycznymi, regulaminów użytkowania komputerów służbowych do pracy zdalnej, instruktażu zgłaszania incydentów oraz obowiązku zapewnienia bezpieczeństwa danych (w tym danych

25 Rozporządzenie Ministra Zdrowia z dnia 13 marca 2020...

26 Ustawa z dnia 2 marca 2020 r. o szczególnych rozwiązaniach związanych z zapobieganiem, przeciwdziałaniem i zwalczaniem COVID-19, innych chorób zakaźnych oraz wywołanych nimi sytuacji kryzysowych (Dz. U. 2020, poz. 1842) - dalej: Specustawa koronawirusowa. 
osobowych), szczegółowo normując ich przetwarzanie w warunkach i w trakcie wykonywania obowiązków poza stacjonarną siedzibą. Należało wziąć pod uwagę kwestie łącza internetowego, bezpiecznego połączenia oraz zdalnego dostępu do systemów teleinformatycznych. Analizowane regulaminy w różnym stopniu określały zasady pobrania dokumentacji papierowej oraz elektronicznej, zapisanej na informatycznych nośnikach danych, poza siedziby urzędów ${ }^{27}$.

Powszechność zdalnej formy pracy przełożyła się na pozytywny stosunek do niej wśród pracowników jednostek objętych badaniem (wykres 4). Ponad 54\% respondentów do pracy w systemie EZD odniosło się pozytywnie, a 35\% określiło swój stosunek jako neutralny. Niewiele ponad $6 \%$ respondentów nie miało doświadczeń pracy w systemie EZD w czasie pandemii, co mogło być spowodowane różnorodnymi czynnikami: nieobejmowaniem przez EZD wybranych klas z wykazu akt, brakiem możliwości technicznych pracy w bezpiecznym środowisku poza siedzibą urzędu oraz niekorzystaniem z systemu z uwagi na specyfikę zajmowanego stanowiska.

Wykres 4. Stosunek pracowników do pracy zdalnej w systemie EZD

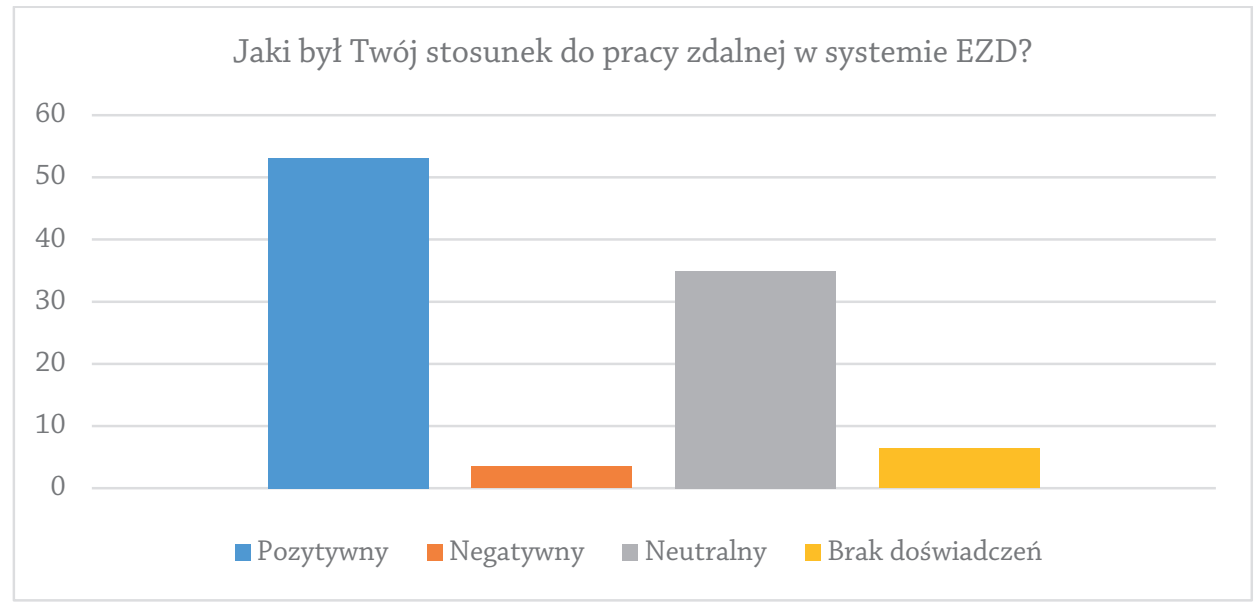

Opracowanie własne na podstawie dokumentacji zebranej w toku projektu.

Okres pandemii wpłynął na gwałtowne przyśpieszenie cyfrowej transformacji w działalność jednostek publicznych ${ }^{28}$. Nagła, wymuszona czynnikami zewnętrznymi sytuacja wywołała pilną potrzebę wdrażania innowacji oraz nowych roz-

27 Na podstawie dokumentacji zebranej w toku projektu.

28 Zob. wykresy 7-8. 
wiązań i praktyk w wirtualnej działalności urzędu. Szersze wykorzystanie poczty elektronicznej było rozwiązaniem i praktyką, które w największym stopniu zyskało na popularności w czasie pandemii (wykres 5). Wynik ten nie zaskakuje, jeśli wziąć pod uwagę, że podmioty same zachęcały do kontaktu elektronicznego przez e-mail. Nie będzie ryzykownym stwierdzenie, że to właśnie ta forma (a nie platforma ePUAP) była najczęściej wybierana przez klientów instytucji. Popularnością cieszyły się również telefoniczne i internetowe umawianie wizyt oraz telekonferencje i pulpit zdalny ${ }^{29}$.

Wykres 5. Rozwiązania z zakresu biurowości wdrożone w związku z epidemią

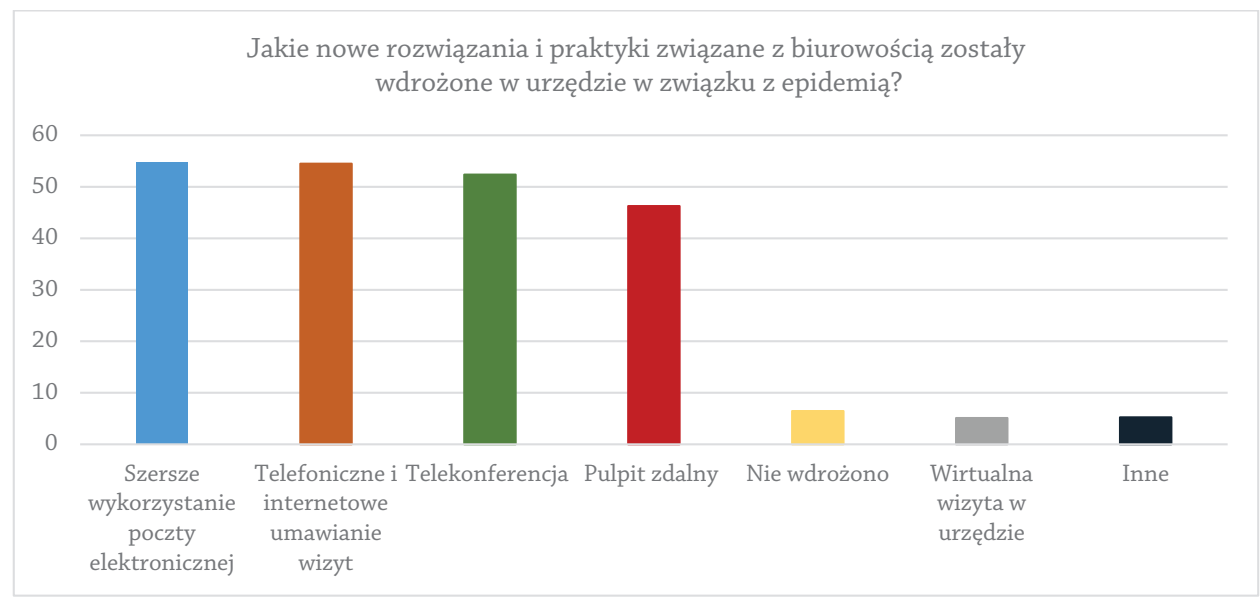

Opracowanie własne na podstawie dokumentacji zebranej w toku projektu.

Ankietowani byli zgodni co do integracji EZD z platformą ePUAP w zakresie pełnej obsługi korespondencji wpływającej za jej pośrednictwem na elektroniczną skrzynkę podawczą (wykres 6). Integracja z pocztą, jak pokazały wyniki, nie jest przeprowadzona w pełni i z pewnością powinna być przedmiotem usprawnienia chociażby w kontekście rejestrowania przesyłek wpływających do urzędów. W praktyce rozwiązania integracji poczty z systemem EZD są różnorodne. Niektóre podmioty wdrożyły pełne połączenie skrzynki ogólnej z systemem, inne jedynie w ramach wiadomości wychodzących bądź tylko w zakresie poczty przychodzącej na adres główny. Skrzynki komórek organizacyjnych niekiedy zintegrowano wyłącznie w zakresie ekspedycji. Dane uzyskane w trybie dostępu

29 Na podstawie dokumentacji zebranej w toku projektu. 
do informacji publicznej nie do końca korespondują z wynikiem badania ankietowego. Według 27\% respondentów system EZD był zintegrowany z pocztą elektroniczną, natomiast - na podstawie informacji otrzymanych bezpośrednio od urzędów - można stwierdzić, że taka integracja nastąpiła w 56\% badanych jednostek. Warto podkreślić, że brak integracji był - w ocenie pracowników -swoistym utrudnieniem nie tylko w czasie pandemii. Dla $13 \%$ ankietowanych system nie był w ogóle zintegrowany, a pamiętać należy, że kompatybilność EZD z innym systemami i oprogramowaniem poczty elektronicznej jest ważnym elementem harmonizacji i pełnego wykorzystania systemu ${ }^{30}$.

Wykres 6. Integracja systemu EZD

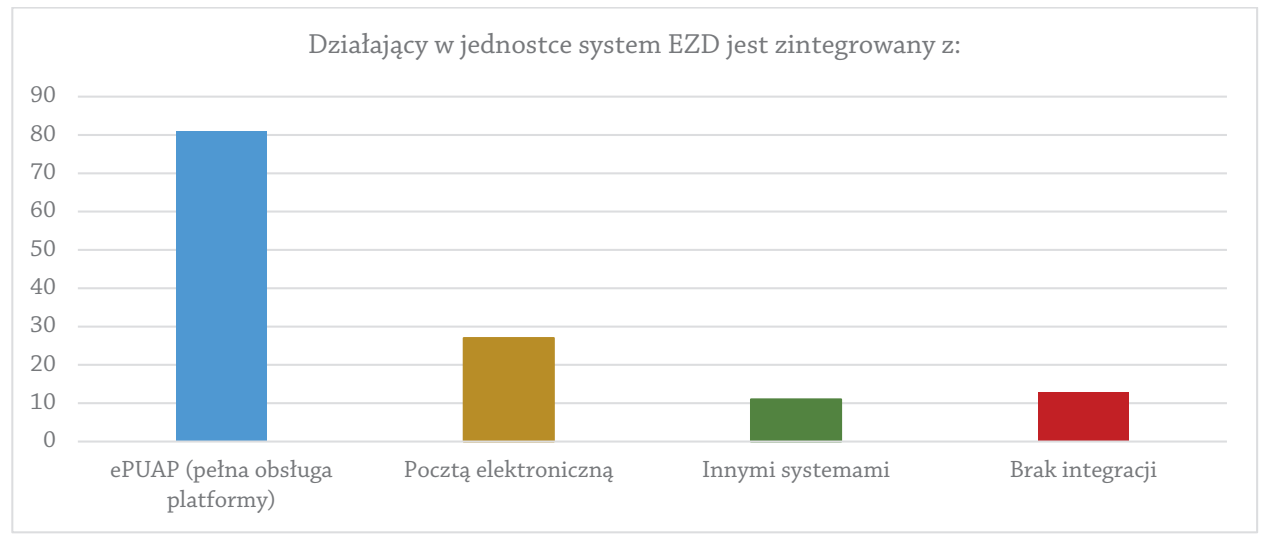

Opracowanie własne na podstawie dokumentacji zebranej w toku projektu.

Nie udało się ustalić mechanizmu usuwania poczty elektronicznej ani jej archiwizowania. Aż 84\% badanych jednostek w tym zakresie wykorzystuje rozwiązania przewidziane w rozporządzeniu Prezesa Rady Ministrów z 2011 r., a 16\% unormowało te kwestie w sposób szczegółowy. Warto zwrócić uwagę, że przepisy wspomnianego rozporządzenia nie są precyzyjne w tym zakresie ${ }^{31}$. Z uwagi na ochronę danych osobowych, ich przetwarzanie powinno odbywać się zgodnie z przepisami szczególnymi. Niektóre z urzędów, choć jest to stosunkowo mała grupa $16 \%$, kwestie te unormowały na podstawie wytycznych od producentów oprogramowania pocztowego, przepisami wewnętrznymi bezpieczeństwa syste-

\footnotetext{
Ibidem.

31 Zob. Rozporządzenie Prezesa Rady Ministrów z dnia 18 stycznia 2011 r. w sprawie instrukcji kancelaryjnej, jednolitych rzeczowych wykazów akt oraz instrukcji w sprawie organizacji i zakresu działania archiwów zakładowych (Dz. U. 2011, nr 14, poz. 67), § 18.
} 
mów IT wykorzystywanych w działalności podmiotów lub zarządzeń określających bezpieczeństwo przetwarzania danych osobowych. Zdarzyły się przypadki traktowania wpływającej poczty elektronicznej na warunkach tożsamych z wpływami tradycyjnymi, a ich archiwizacja odbywała się na zasadach ogólnych ${ }^{32}$.

Rozporządzenie Prezesa Rady Ministrów z 18 stycznia 2011 r. jest dla zdecydowanej większości badanych jednostek aktem normującym zasady postępowania z dokumentacją elektroniczną napływającą na adres poczty elektronicznej, adresy pracowników oraz elektronicznej skrzynki podawczej. Jedynie $24 \%$ badanych podmiotów uszczegółowiło zasady określone w rozporządzeniu w formie zarządzenia kierownika jednostki. Warto zwrócić w tym miejscu uwagę, że zarządzenia wewnętrzne określające zasady postępowania z dokumentacją (w tym dokumentacją elektroniczną) nie zawsze nosiły nazwę „instrukcji kancelaryjnej”. Były to niekiedy „regulaminy użytkownika EZD”, „zasady wykonywania czynności kancelaryjnych”, a nawet „regulaminy organizacyjne”. Wobec tego należy zasygnalizować negatywną praktykę rozproszenia norm wytwarzania i przechowywania dokumentacji, częściowo zapewne powodowaną ograniczeniami wynikającymi z rozporządzenia Prezesa Rady Ministrów z 2011 r., a także postępującą informatyzacją ( $z$ uwagi na potrzebę integracji z systemem EZD wykorzystywanych systemów tzw. dziedzinowych oraz innych systemów teleinformatycznych). Rodzi to pytania dotyczące nadzoru nad narastającym zasobem archiwalnym poprzez kontrolę tych wewnętrznych, wdrażanych doraźnie wobec wprowadzania EZD, normatywów oraz o wpływ państwowej służby archiwalnej na ich kształt, a w konsekwencji - biurowość wytwórców zasobu archiwalnego. Zrealizowane badania ujawniły te niepokojące praktyki, które zasługują na pilną, szerszą, naukową diagnostykę badawczą.

\section{System EZD w czasie pandemii}

Długotrwały stan nadzwyczajny ingerował w wiele aspektów życia człowieka, m.in. - jak już zostało wielokrotnie podkreślone - jego przemieszczanie się i ograniczenie rozlicznych aktywności życia społecznego. W sytuacji zagrożenia naturalnym był zwrot do świata cyfrowego, a w kontekście funkcjonowania administracji samorządowej i rządowej w terenie - konieczność wzajemnego kon-

32 Na podstawie dokumentacji zebranej w toku projektu. 
taktowania się na odległość. Respondenci badania w zdecydowanej większości (ponad 75\%) zauważyli w otoczeniu swoich instytucji wzrost zainteresowania innymi, tj. nietradycyjnymi, formami załatwiania spraw (wykres 7) w okresie tzw. pierwszego lockdownu, czyli wiosną 2020 r.

Wykres 7. Zainteresowanie załatwianiem spraw urzędowych na odległość w okresie tzw. pierwszego lockdownu

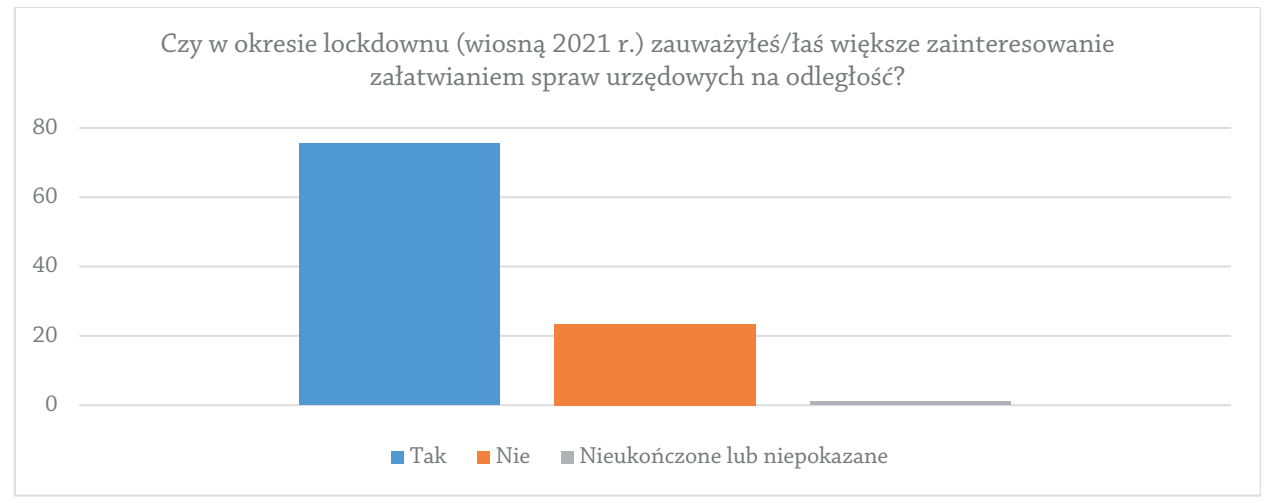

Opracowanie własne na podstawie dokumentacji zebranej w toku projektu.

Uczestnicy badania ankietowego jednoznacznie zgodzili się ze stwierdzeniem, że pandemia koronawirusa SARS-CoV-2 i powodowanej nim jednostki chorobowej układu oddechowego COVID-19 spowodowała upowszechnienie i ułatwienie dostępu do usług publicznych i załatwiania spraw za pomocą narzędzi cyfrowych. Takiego zdania było niemal 83\% urzędników (wykres 8). Warto przy tym zwrócić uwagę, że taki stan nie wyniknął w związku z jakimikolwiek działaniami inicjowanymi przez władze różnych szczebli (tzn. akcjami promującymi e-usługi, wdrożeniami nowych narzędzi informatycznych, poszerzeniem katalogu spraw możliwych do załatwienia na odległość), a wyłącznie jako następstwo stanu epidemii ${ }^{33}$.

Wspomniane upowszechnienie narzędzi cyfrowych znalazło potwierdzenie w danych zebranych drogą dostępu do informacji publicznej. Do jednostek organizacyjnych wytypowanych do badania przesłano zapytanie o liczbę przesyłek wpływających w postaci elektronicznej na przestrzeni lat 2019-2020 w ujęciu miesięcznym (wykres 9). Odpowiedzi wyraźnie wskazały na wzrost przypadający na r. 2020, szczególnie w okresie dwóch fal występowania wzmożonego zagroże-

33 Na podstawie dokumentacji zebranej w toku projektu. 
Wykres 8. Upowszechnienie i ułatwienie dostępu do usług publicznych i załatwiania spraw za pomocą narzędzi cyfrowych w obliczu pandemii COVID-19

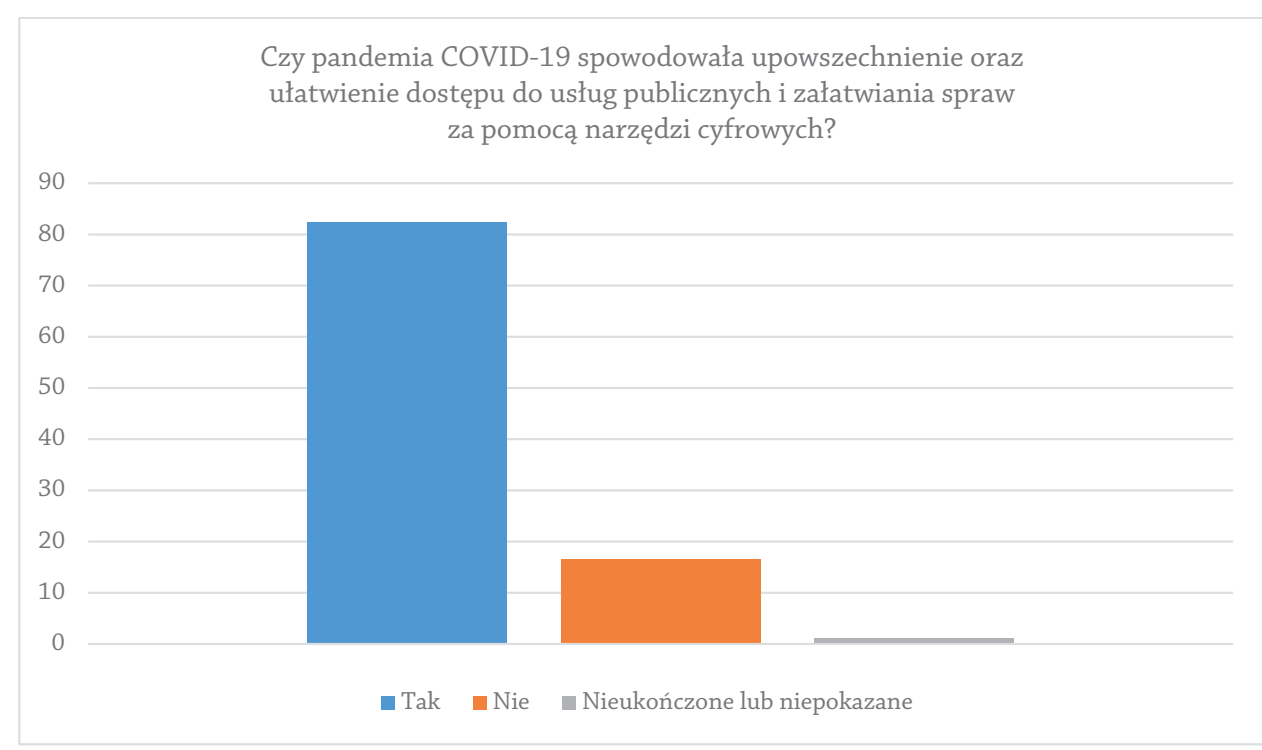

Opracowanie własne na podstawie dokumentacji zebranej w toku projektu.

Wykres 9. Liczba pism wpływających przez platformę ePUAP w latach 2019-2020

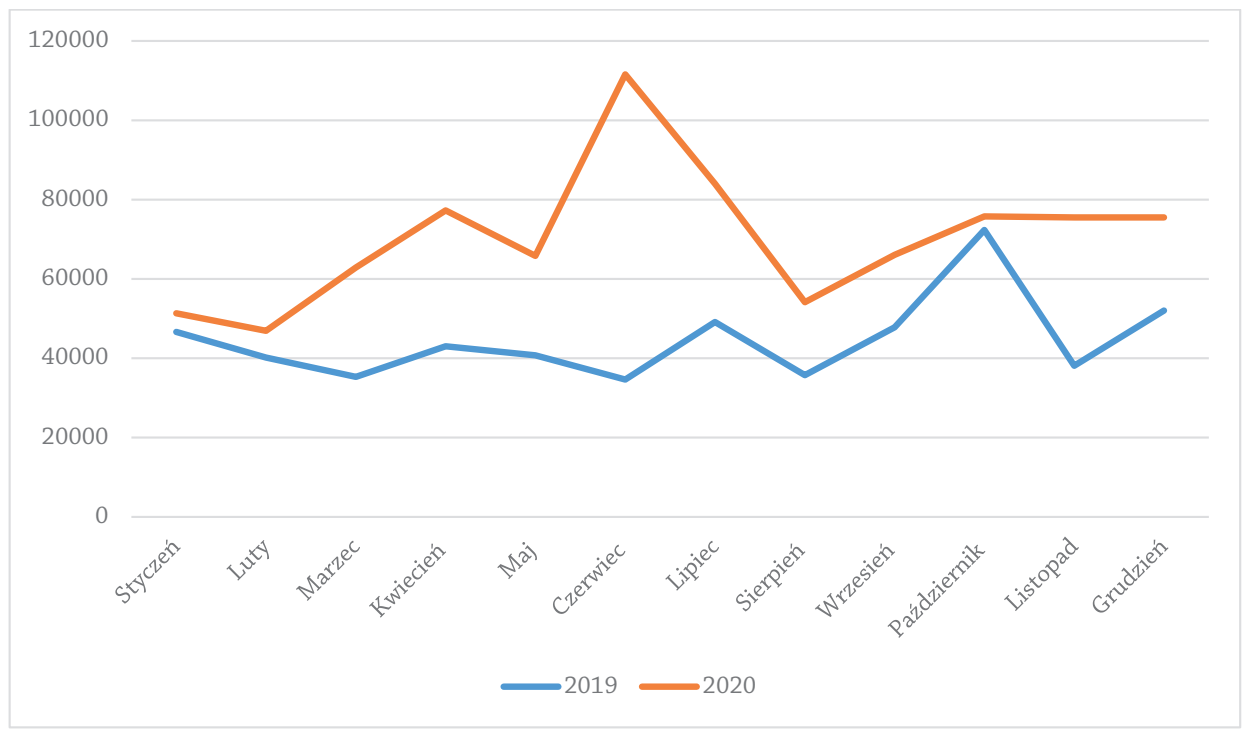

Opracowanie własne na podstawie dokumentacji zebranej w toku projektu. 
nia epidemicznego - od marca do czerwca, a następnie od października do końca roku. W skali rocznej tendencja wzrostowa również była wyraźna ${ }^{34}$. Ogółem w 2020 r. przez platformę ePUAP wpłynęło do urzędów niemal 37\% więcej pism niż w roku poprzednim. Dane te korespondują z informacjami publikowanymi przez Ministerstwo Cyfryzacji i Instytut Łączności - Państwowy Instytut Badawczy. W całym 2020 r. przez platformę ePUAP ogólnych pism do urzędów wpłynęło o $22 \%$ więcej niż w roku poprzednim ${ }^{35}$.

Zainteresowanie obywateli usługami świadczonymi elektronicznie wzrosło w obliczu pandemii, a platforma ePUAP była coraz częściej wykorzystywana jako sposób komunikacji z jednostkami samorządowymi i administracji rządowej w terenie. Na znaczeniu zyskały rozwiązania informatyczne umożliwiające efektywne dokumentowanie przebiegu załatwiania spraw urzędowych. Mowa tu przede wszystkim o wdrożonym systemie EZD jako podstawowym narzędziu teleinformatycznym służącym codziennemu wykonywaniu czynności kancelaryjnych. Jego jakość, niezawodność w sytuacji kryzysowej, możliwość niemal pełnego przeniesienia świadczenia stosunku pracy poza stacjonarne siedziby urzędów miały kluczowe znaczenie dla zachowania efektywności działań równej tej, którą odnotowywano przed wybuchem epidemii koronawirusa SARS-CoV-2. Znaczenie wykorzystywanego (wykres 10) systemu EZD w kontekście wydajności pracy urzędu oceniono w większości pozytywnie, choć należy zwrócić uwagę na duże, bo sięgające niemal 25\% respondentów, grono osób niezdecydowanych (wskazujących odpowiedź „trudno powiedzieć”) oraz niemal 12\% ankietowanych, którym w osiągnięciu efektywności przeszkodziły ograniczenia techniczne (np. brak możliwości pracy w domu) ${ }^{36}$.

System EZD wykorzystywany w podmiotach objętych badaniem dla zdecydowanej większości użytkowników był skutecznym narzędziem dokumentowania przebiegu załatwiania spraw w sytuacji kryzysowej i sprawdził się jako podstawowe narzędzie, w którym wykonywano czynności kancelaryjne (wykres 11). Przeciwnego zdania było niespełna 20\% ankietowanych urzędników. Współczynnik ten koresponduje ze wskazaniami dotyczącymi zgłaszania incydentów lub problemów związanych z funkcjonowaniem systemu EZD (wykres 12). Ponad 76\% respondentów nie napotkało większych trudności w zakresie jego wykorzysty-

34 Ibidem.

35 Pismo ogólne do podmiotu publicznego - stary wzór, https://widok.gov.pl/services/ePUAP-Pismo-ogolne-do-podmiotu-publicznego-stary-wzor/ [dostęp: 13.05.2021].

36 Na podstawie dokumentacji zebranej w toku projektu. 
Wykres 10. Wydajność pracy w okresie pandemii a system EZD

\section{Czy system EZD pozwolił na wydajną pracę urzędu,} równą osiąganej przed epidemią?

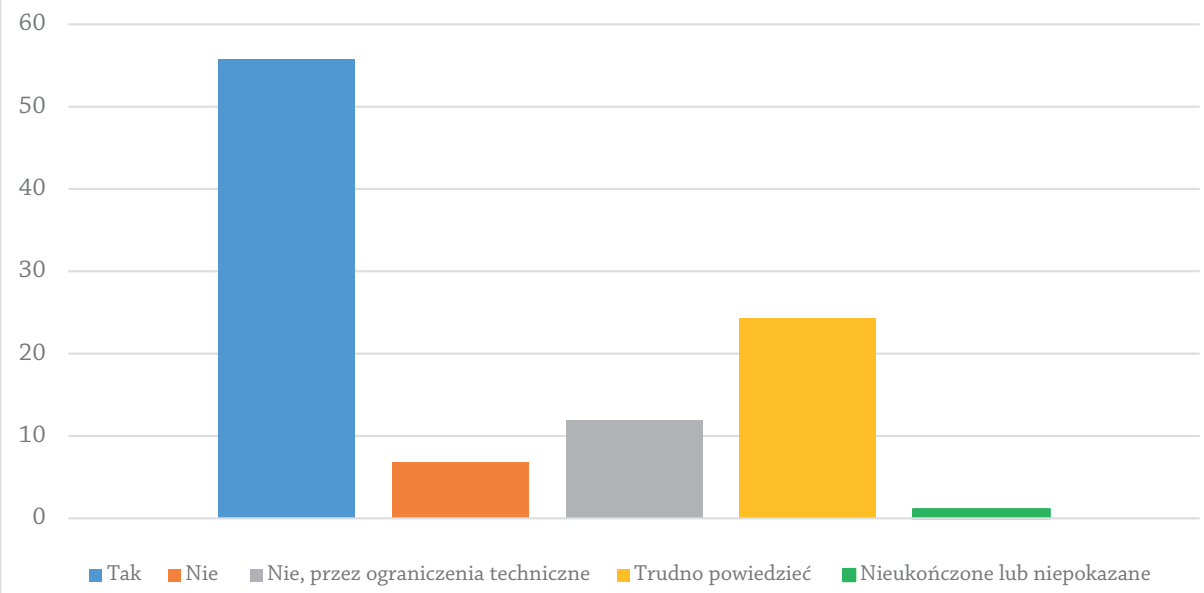

Opracowanie własne na podstawie dokumentacji zebranej w toku projektu.

Wykres 11. Skuteczność sytemu EZD w sytuacji kryzysowej

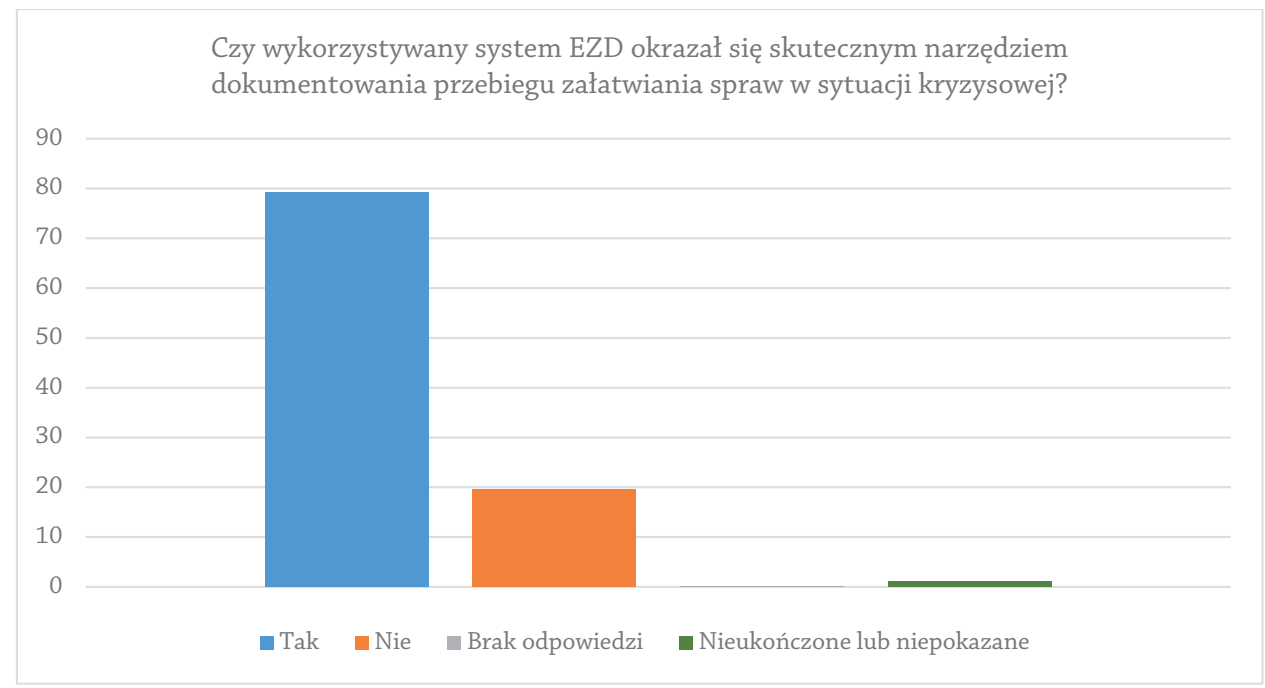

Opracowanie własne na podstawie dokumentacji zebranej w toku projektu. 
wania w okresie pandemii, choć zwracano uwagę m.in. na: kłopoty przy wyszukiwaniu adresatów, brak możliwości podglądu wszystkich spraw do załatwienia, utrudnione podpisywanie pism, powolne działanie systemu, błędy związane $\mathrm{z}$ aktualizacją, problemy z dostępem do zasobów sieciowych, brak możliwości otwierania załączników. Zauważono jednak, że trudności występowały sporadycznie oraz były na ogół szybko niwelowane ${ }^{37}$.

Wykres 12. Problemy związane z funkcjonowaniem systemu EZD

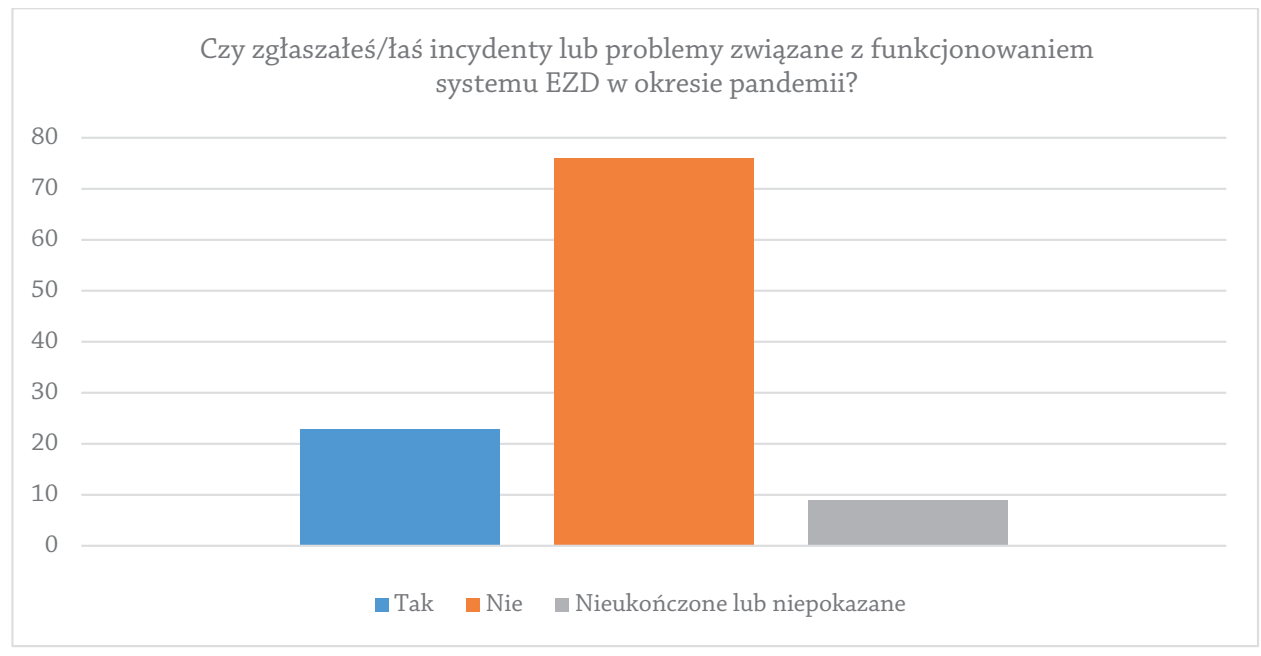

Opracowanie własne na podstawie dokumentacji zebranej w toku projektu.

W żadnej z badanych jednostek nie stwierdzono poważniejszych awarii systemu EZD, natomiast niektóre informowały o czasowej niedostępności platformy ePUAP ${ }^{38}$. Nie oznacza to jednak, że praca w nowej, zmienionej covidowymi obostrzeniami rzeczywistości była wolna od utrudnień. Do najczęściej wskazywanych należało przeciążenie systemu EZD, który tracił płynność pracy. Drugim problemem występującym z największą częstotliwością były awarie sprzętu i narzędzi informatycznych (w tym sieci, systemu EZD, platformy ePUAP). Ponad 26\% urzędników miało trudności ze zbyt wolnym połączeniem internetowym, tyle samo w ogóle nie miało dostępu do systemu EZD podczas pracy zdalnej. Niemal jeden na pięciu respondentów nie otrzymał do dyspozycji komputera służbowego. Podobnie zarysował się problem braku dostępu do systemów, rejestrów

37 Na podstawie dokumentacji zebranej w toku projektu.

38 Ibidem. 
oraz baz danych wykorzystywanych w toku pracy. Do zdecydowanie rzadszych barier należały utrudnienia związane z niewdrożeniem wcześniej podpisu elektronicznego lub podpisu $\mathrm{z}$ wykorzystaniem profilu zaufanego oraz brak możliwości zorganizowania bezpiecznego środowiska pracy. Pozytywnie należy odebrać fakt, że blisko 25\% urzędników nie napotkało żadnych problemów w pracy podczas pandemii COVID-19 (wykres 13).

Wykres 13. Problemy i trudności w pracy w okresie epidemii COVID-19

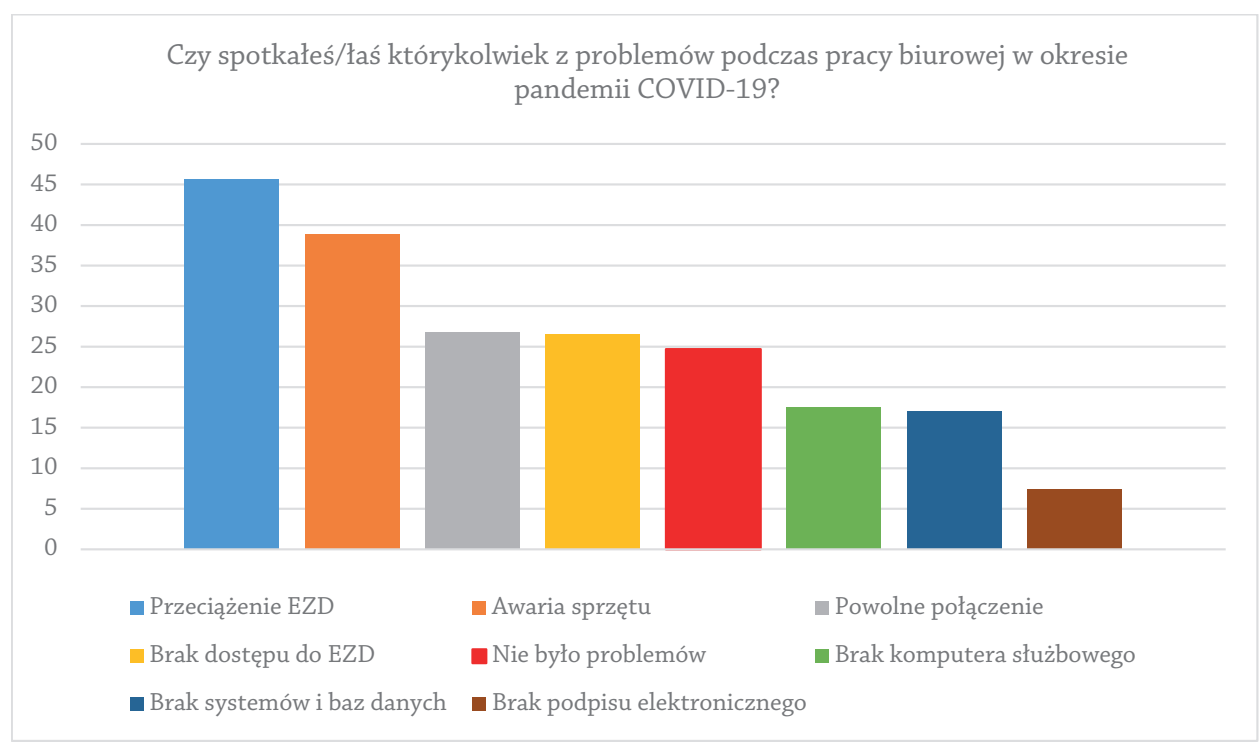

Opracowanie własne na podstawie dokumentacji zebranej w toku projektu.

Pomimo zdiagnozowanych problemów i trudności w codziennej pracy, które jak udało się ustalić - dotyczyły niekiedy niewystarczającej wydajności systemu EZD, zdecydowana większość (bo niemal aż 90\%) uczestników badania doceniła to narzędzie informatyczne jako wspomagające pracę podmiotu na tyle, by polecić jego wdrożenie tym jednostkom, które do tej pory nie zdecydowały się na ten $\mathrm{krok}^{39}$.

Jak zaakcentowano powyżej, oddzielną, nieobjętą pełnym badaniem ani ankietyzacją grupę badawczą stanowiły podmioty, w których zdecydowano o wdrożeniu systemu EZD po wybuchu epidemii koronawirusa SARS-CoV-2, tj. od marca 2020 r. Do tych podmiotów złożono wniosek o udostępnienie 
informacji publicznej z zapytaniem o powody podjęcia decyzji o przejściu na kancelarię w pełni elektroniczną. Należy stwierdzić, że dla przeważającej części jednostek pandemia COVID-19 nie była bezpośrednią przyczyną rozpoczęcia działań związanych z wdrożeniem systemu. Jedynie $10 \%$ podmiotów poinformowało, że postępująca od początku marca 2020 r. sytuacja epidemiczna stanowiła główny asumpt do pełnego wprowadzenia EZD do działalności jednostek. Znacznie częściej informowano, że pandemia i związane z nią doświadczenia z zakresu biurowości utwierdziły o słuszności podjętej wcześniej decyzji ${ }^{40}$.

\section{Wyposażenie techniczne}

Zagadnienie wyposażenia technicznego, jego jakość, sprawność oraz dostępność, kwestia nader ważna dla wydajnej pracy każdej jednostki organizacyjnej, w obliczu pandemii nabrała jeszcze większego znaczenia. Jednostki administracji samorządowej i rządowej w terenie, w których działania kancelarii organizowano w sposób w pełni zinformatyzowany, powinny były z większą łatwością przejść do trybu pracy zmianowej lub w pełni zdalnej niż podmioty funkcjonujące w systemie tradycyjnym ${ }^{41}$. Przeniesienie działalności do świata wirtualnego nie przynosiło $\mathrm{w}$ nich bowiem radykalnych zmian $\mathrm{w}$ sposobach wykonywania czynności kancelaryjnych - nadal służyły im głównie narzędzia informatyczne oraz sprzęt komputerowy. Mimo to konieczność organizowania pracy biurowej poza siedzibami urzędów implikowała potrzebę dysponowania specjalnym sprzętem. Zaliczyć do niego można m.in. laptopy, tablety, urządzenia umożliwiające korzystanie z zasobów sieciowych, oprogramowanie do korzystania z pulpitu zdalnego.

Trudności związane z zapewnieniem właściwego wyposażenia nie zostały w pełni zniwelowane przez zgodę na korzystanie z urządzeń prywatnych urzędników, dodatkowo opatrzone wymaganiem spełnienia ustawowych wymogów bezpieczeństwa ${ }^{42}$. W obliczu pandemii powszechne były zakupy nowego wyposażenia. Aż w 89\% przebadanych jednostek od marca 2020 r. zakupiono sprzęt

\footnotetext{
40 Ibidem.

41 W systemie tradycyjnym zgodnie z przepisami rozporządzenia Prezesa Rady Ministrów z 18 stycznia 2011 r.

42 Specustawa koronawirusowa, art. 3, ust. 5.
} 
informatyczny niezbędny do pracy biurowej. Były to bardzo duże inwestycje, nie niższe niż na sumę wydatków wynoszącą 7634 854,23 zł. Zakupiono głównie laptopy oraz tablety, a także drobny sprzęt: drukarki, routery, kamery internetowe oraz dyski zewnętrzne. W niektórych jednostkach zamówienia sięgały aż kilkuset urządzeńn ${ }^{43}$.

\section{Przygotowanie merytoryczne}

Jak zaakcentowano powyżej, wdrożenie w działalności podmiotu systemu EZD jest dużym przedsięwzięciem technicznym i merytorycznym. Wykorzystanie tego narzędzia wiąże się z wieloma zmianami w codziennym urzędowaniu, co stanowi wyzwanie dla wszystkich zatrudnionych. Konieczne jest więc gruntowne przeszkolenie pracowników i systematyczne podnoszenie ich kompetencji w zakresie nie tylko dokumentowania spraw i jego przebiegu, ale także wykorzystania narzędzi informatycznych, które cechują się przecież dużą dynamiką. Jednostki, które wdrażały system zgodnie z przyjętym harmonogramem, określały poszczególne etapy szkoleń pracowników - późniejszych użytkowników systemu. Można zatem domniemywać, że poziom przeszkolenia urzędników w tych podmiotach był wyższy niż w jednostkach, w których system EZD wdrożono częściowo lub nie uczyniono tego w ogóle.

Jak udało się ustalić, zdecydowana większość ankietowanych pozytywnie oceniła wykorzystanie systemu EZD, co należy niewątpliwe powiązać ze sprawnym wykorzystywaniem wiedzy, umiejętności i kompetencji teleinformatycznych zdobytych wcześniej. Doświadczenia te w obliczu sytuacji kryzysowej zostały poddane szczególnej próbie. Nie można jednoznacznie ocenić, że pandemia uwidoczniła braki w przygotowaniu merytorycznym urzędników, choć w odpowiedziach otwartych respondenci postulowali zwiększenie liczby szkoleń. Nieznaczna większość, bo 51\% ankietowanych zauważyło, że pandemia nie wywołała potrzeby poszerzenia umiejętności i wiedzy. Przeciwnego zdania była grupa $48 \%$ uczestników badania, a 1\% pozostał bez opinii w tym zakresie.

43 Na podstawie dokumentacji zebranej w toku projektu. 


\section{Podsumowanie}

W oparciu o zebrany materiał badawczy jednoznacznie należy stwierdzić, że system EZD okazał się skutecznym narzędziem nie tylko w codziennej pracy podmiotów, ale także w obliczu sytuacji kryzysowej, odgrywając ogromną rolę w zachowaniu sprawności funkcjonowania urzędów. Uczestnicy badania wskazali, że pełna informatyzacja biurowości pozwoliła na zachowanie dotychczasowej wydajności pracy oraz zalecali wdrażanie systemów EZD tym jednostkom, które jeszcze tego nie dokonały. Należy jednak odnotować także trudności pojawiające się w toku pracy wykonywanej w nowych realiach (m.in. przeciążenie narzędzi informatycznych, awarie sprzętów, zbyt powolne łącza internetowe), choć warto podkreślić, że niemal jeden na czterech urzędników nie napotkał problemów w związku ze świadczeniem pracy.

Bezsprzecznym faktem jest, że epidemia COVID-19 i jej skutki, w tym szczególnie obostrzenia sanitarne zapobiegające rozprzestrzenianiu się koronawiursa SARS-CoV-2, spowodowały upowszechnienie i ułatwienie dostępu do załatwiania spraw na odległość. W okresie pandemii znacznie częściej wykorzystywano platformę ePUAP do kontaktów obywatela z urzędem. Trend rosnący pokrywał się z kolejnymi falami wzrastania liczby zakażeń koronawirusem.

Wyniki przeprowadzonego badania pozwalają zwrócić uwagę na ważne aspekty związane z planowaniem wdrożenia systemu EZD w podmiotach oraz związane z tym problemy natury technicznej i organizacyjnej. Jako niepokojące zjawisko należy ocenić brak planowania w zakresie rozwoju teleinformatycznego jednostek, w tym informatyzacji biurowości. W większości przebadanych podmiotów podjęcie decyzji o wdrożeniu EZD i sam proces wdrożenia nie były przedmiotem działań o charakterze strategicznym. Co więcej, z badania wynika duża różnorodność przyjętych rozwiązań organizacyjnych i funkcjonowania urzędów w okresie przejściowym. Można więc stwierdzić, że pełne wprowadzenie systemu EZD jest dobrym kierunkiem, do którego prowadzą różne, nie zawsze przemyślane i właściwie zaplanowane, drogi. Kancelaria ma kluczowe znaczenie dla wydajności pracy urzędu oraz jest miejscem wytwarzania materiałów archiwalnych. Przyjmowane w niej rozwiązania powinny być zatem bardzo dobrze przemyślane oraz skrojone pod konkretne potrzeby, a działania poczynione ad hoc mogą okazać się niewystarczające i nieefektywne w dłuższej perspektywie czasowej.

Epidemia COVID-19 spowodowała, że podmioty musiały inwestować w sprzęt informatyczny niezbędny do pracy biurowej. Potrzeba inwestycji była powszech- 
na: niemal 90\% jednostek zakupiło różnorakie urządzenia, szczególnie komputery przenośne, tablety, oprogramowanie.

Elektroniczna kancelaria wymaga od urzędników znajomości nie tylko procedur postępowania z dokumentacją (szczególnie instrukcji kancelaryjnej), ale także - jak pokazało badanie - licznych, rozproszonych, wewnętrznych i powszechnie obowiązujących przepisów oraz norm dotyczących bezpieczeństwa teleinformatycznego, zagrożeń w cyberprzestrzeni oraz zasad bezpiecznego przetwarzania danych osobowych. Zasadnym więc staje się postulat o potrzebę stałego dokształcania urzędników, kształcenia na studiach podyplomowych, szkoleń zewnętrznych oraz wewnętrznych - organizowanych przez koordynatorów czynności kancelaryjnych i archiwistów. Respondenci badania jako czynnik ograniczający ich kwalifikacje spowodowany sytuacją epidemiczną wskazali brak możliwości wymiany doświadczeń w miejscu pracy. Należy zatem organizować przestrzeń do wymiany poglądów, zdobytych kompetencji i wiedzy.

Postępująca od początku marca 2020 r. sytuacja epidemiczna postawiła przed polską administracją samorządowa i rządową w terenie wiele nieznanych dotąd wyzwań. Organizacja pracy zdalnej i rotacyjnej, ograniczenie kontaktów z otoczeniem zewnętrznym, wykonywaniesłużbowych obowiązków w reżimie sanitarnym oraz - w końcu - powszechna obawa przed zakażeniem spowodowały, że lata 2020-2021 będą długo wspominane jako trudne, a różnorakie skutki (m.in. ekonomiczne, społeczne, kulturowe) z pewnością pozostaną odczuwalne przez długi czas.

\section{Źródła}

National Archives, Record Group 165, Records of the War Department General and Specific Staffs, 1860-1952, Medical Department - Influenza Epidemic 1918 - Masks for protection against influenza. Girl clerks in New York at work with masks carefully tied about their faces, sygn. 165-WW-269B24.

Dane badawcze zgromadzone w toku realizacji projektu przechowywane w siedzibie Wydziału Nauk Historycznych Uniwersytetu Mikołaja Kopernika w Toruniu, ul. Wł. Bojarskiego 1, 87-100 Torun.

Pismo ogólne do podmiotu publicznego - stary wzór, https://widok.gov.pl/services/ePUAP-Pismo-ogolne-do-podmiotu-publicznego-stary-wzor/ [dostęp: 13.05.2021]. 
Rozporządzenia Prezesa Rady Ministrów z dnia 18 stycznia 2011 r. w sprawie instrukcji kancelaryjnej, jednolitych rzeczowych wykazów akt oraz instrukcji w sprawie organizacji i zakresu działania archiwów zakładowych (Dz. U. 2011, nr 14, poz. 67).

Rozporządzenia Rady Ministrów w sprawie ustanowienia określonych ograniczeń, nakazów i zakazów w związku z wystąpieniem stanu epidemii (Dz. U. 2020, poz. 658; Dz. U. 2020, poz. 697; Dz. U. 2020, poz. 792; Dz. U., 2020, poz. 878; Dz. U. 2020, poz. 964; Dz. U. 2020, poz. 1066; Dz. U. 2020, poz. 1356; Dz. U. 2020, poz. 1758; Dz. U. 2020, poz. 2091; Dz. U., 2020, poz. 2132; Dz. U. 2020, poz. 2316; Dz. U. 2021 poz. 447; Dz. U. 2021, poz. 512).

Rozporządzenie Ministra Zdrowia w sprawie ogłoszenia na obszarze Rzeczypospolitej Polskiej stanu zagrożenia epidemicznego (Dz. U. 2020, poz. 433).

Ustawa z dnia 17 lutego 2005 r. o informatyzacji działalności podmiotów realizujących zadania publiczne (Dz. U. 2021, r. poz. 670).

Ustawa z dnia 2 marca 2020 r. o szczególnych rozwiązaniach związanych z zapobieganiem, przeciwdziałaniem i zwalczaniem COVID-19, innych chorób zakaźnych oraz wywołanych nimi sytuacji kryzysowych (Dz. U. 2020, poz. 1842).

Wyniki badania ankietowego „Wpływ epidemii COVID-19 na informatyzację biurowości w administracji publicznej”, https://dobrepraktyki.umk.pl/pages/dane_badawcze/ [dostęp: 12.06.2021].

\section{Bibliografia}

Erkoreka A., The Spanish influenza pandemic in occidental Europe (1918-1920) and victim age, „Influenza Other Respir Viruses” 2010, nr 4 (2), s. 81-89.

Ewing, E.T., Reznick J.S., Clerks wearing masks. Building Historical Empathy while Teaching the 1918 Influenza Epidemic, https://www.historians.org/publications-and-directories/perspectives-on-history/december-2020/clerks-wearing-masks-building-historical-empathy-while-teaching-the-1918-influenza-epidemic [dostęp: 5.05.2021].

Komunikat Centralnej Komisji Usprawnienia Administracji Publicznej przy Prezesie Rady Ministrów, nr 3, Zagadnienie mechanizacji pracy biurowej, oprac. W. Jarzębowski, W. Jaroszewska, Warszawa 1955.

Kraines O., The President versus Congress: The Keep Commission, 1905-1909: First Comprehensive Presidential Inquiry into Administration, „The Western Political Quarterly” 1970, t. 23, nr 1, s. $5-54$.

Moe R.C., Reorganizing the Executive Branch in the 20th Century: Landmark Commissions, Waszyngton, D.C. 2002, https://digital.library.unt.edu/ark:/67531/metadc813148/ [dostęp: 13.05.2021]. 
Pemberton W.E., Struggle for the New Deal: Truman and the Hoover Commission, „Presidential Studies Quarterly" 1986, t. 16, nr 3, s. 511-527.

Pepłowska K., Biurowość w czasach pandemii. Wpływ epidemii COVID-19 na informatyzację biurowości w jednostkach administracji samorządowej, „Archeion” 2021, t. 122, DOI: 10.4467/26581264AR C.21.008.14488.

Smoczyński M., Amerykańskie i polskie poczq̨tki zarzqdzania dokumentacją, [w:] Pogranicza archiwistyki, Toruńskie Konfrontacje Archiwalne, t. 6, red. W. Chorążyczewski, A. Rosa, Toruń 2019, s. $143-145$

Smoczyński M., Racjonalizacja biurowości w działaniach komisji dla usprawnienia administracji publicznej w II Rzeczypospolitej, [w:] Dzieje biurokracji, t. 10, red. A. Górak, J. Kukarina, D. Magier, Lublin 2019, s. 143-158.

Wpływ cyfryzacji na działanie urzędów administracji publicznej w Polsce w 2014 r. Raport Ministerstwa Administracji i Cyfryzacji, https://dane.gov.pl/media/resources/20150227/PBSMACCyfryzacjaFIN2014.pdf [dostęp: 30.05.2021].

Zestawienie instytucji wdrażających system EZD PUW na podstawie porozumienia z wojewodą podlaskim, https://ezd.gov.pl/www/ezd/partnerzy [dostęp: 6.05.2021]. 